IZA DP No. 7870

Chinese Unions and Enterprises Performance

Tony Fang

Ying Ge

December 2013 


\title{
Chinese Unions and Enterprises Performance
}

\author{
Tony Fang \\ Monash University, \\ University of Toronto and IZA \\ Ying Ge \\ School of International Trade and Economics, Beijing
}

Discussion Paper No. 7870

December 2013

\author{
IZA \\ P.O. Box 7240 \\ 53072 Bonn \\ Germany \\ Phone: +49-228-3894-0 \\ Fax: +49-228-3894-180 \\ E-mail: iza@iza.org
}

Any opinions expressed here are those of the author(s) and not those of IZA. Research published in this series may include views on policy, but the institute itself takes no institutional policy positions. The IZA research network is committed to the IZA Guiding Principles of Research Integrity.

The Institute for the Study of Labor (IZA) in Bonn is a local and virtual international research center and a place of communication between science, politics and business. IZA is an independent nonprofit organization supported by Deutsche Post Foundation. The center is associated with the University of Bonn and offers a stimulating research environment through its international network, workshops and conferences, data service, project support, research visits and doctoral program. IZA engages in (i) original and internationally competitive research in all fields of labor economics, (ii) development of policy concepts, and (iii) dissemination of research results and concepts to the interested public.

IZA Discussion Papers often represent preliminary work and are circulated to encourage discussion. Citation of such a paper should account for its provisional character. A revised version may be available directly from the author. 
IZA Discussion Paper No. 7870

December 2013

\section{ABSTRACT}

\section{Chinese Unions and Enterprises Performance}

This paper uses the national firm level survey data to investigate the effects of Chinese unions on firm performance. We show that Chinese unions have a strong "State-Party voice" face and a "collective voice" face but lack of "monopoly" face. The government influence plays an important role in unionization. The empirical findings on the effectiveness of unions are remarkable: unions in the workplace significantly improve productivity but reduce enterprise profitability. Moreover, the presence of unions in same region and industry generates negative spillovers on enterprise performance.

JEL Classification: J51, J52, J53

Keywords: $\quad$ unions, laws, productivity, profitability, China

Corresponding author:

Tony Fang

Monash University

Department of Management

PO Box 197

Caulfield Vic 3145

Australia

E-mail: tony.fang@monash.edu 


\section{Introduction}

While the unions in developed countries, especially in the United States, have been studied extensively, very few studies focus on the experience of developing countries. When discussing future extensions in this field, Freeman (2005) pointed out that:

More research resources should go to studying how unions operate under the far wider range of economic and social structures outside the United States, in particular to the potential development of real unions in China, and union activity in India and other large developing countries, that compete with us in world markets through low wages. (2005: 663)

What do unions do in China? There is a popular view that China has no "real" unions because the so-called "unions" in China are very different from that in the advanced economy. For example, Chinese unions are not politically independent but are controlled by the State-Party through a hierarchical system. Union officials are usually not elected by the union members but appointed by the State-Party and belong to the government administration. Unions have a weak bargaining power in collective consultation/bargaining with management, and they are sometimes subordinated to management. A unique feature of Chinese unions is that they have multiple objectives: to assist the State-Party in an administrative function to maintain social and political stability, to collaborate with the management to improve production efficiency, and to represent and protect the interests of employees. These objectives are not necessarily in harmony and are increasingly becoming contradictory, especially in the non-state sector.

In this paper we treat Chinese unions as a special form of labor institution operating in a unique social and economic environment, and use the enterprise population level data to investigate the activities and effectiveness of this labor institution. Our data are drawn from the First National Economic Census in 2004 conducted by the National Bureau of Statistics of China (NBSC). To date this is the most comprehensive firm-level micro data set in China, 
which covers entire population of Chinese enterprises, and it is the first economic census reporting the information on workplace unions.

First, we discuss union activities and the unionization process in China. Chinese unions have a strong "State-Party voice" face and are typically subordinated to the State-Party and function as a "transmission belt" through which the State-Party could reach the majority of workers. The State-Party's political influence plays an important role in unionization. The unionization is the highest for state-owned enterprises (SOEs) and the lowest for the private and wholly foreign-owned enterprises (WFOEs). Chinese unions lack a “monopoly” face since they have a weak bargaining power in collective consultation/bargaining with management. The collective labor contracts only include the minimum terms and conditions of employment that are already prescribed by the labor laws and regulations. However, Chinese unions have a "collective voice” face and significant welfare functions. They take part in a wide range of activities such as accepting employee grievances, mediating labor disputes, monitoring the implementation of labor law, providing various services and welfare benefits to employees, promoting technology innovation and employee training, and participating in corporate governance and policy making.

By using the national firm-level dataset to examine the determinants of unionization in China, we also found that the government influence plays an important role in the negotiation between ACFTU and enterprise management (Fang and Ge, 2012). The enterprises that are more attached to the State-Party, such as SOEs, are more likely to establish unions. The higher administrative level the firms are subordinated to, the more likely the firms are unionized. In contrast, those that are less influenced by the government, such as private firms and WFOEs, are less likely to be unionized.

Next, we investigate the linkage between unionization and firm performance. The empirical findings suggest Chinese unions have "real” effects on the enterprises: the presence 
of unions in the workplace is positively associated with the enterprise employee training and productivity, but negatively related to enterprise profitability. Moreover, the presence of unions in the same region and industry generates positive spillovers on employee welfare, but negative spillovers on enterprise performance.

This paper is organized as follows: Section 2 discusses the unique features and various activities of unions in China. Section 3 examines the linkages between unionization and economic performance. Section 4 concludes the paper.

\section{Labor Laws and Unions in China}

The close linkage between legal institutions and economic development has long been recognized. On the one hand, the presence of legal institutions is one of the important determinants of economic development, which requires a legal order offering stable and predictable rights of property and contract (North 1990). On the other hand, the improvement of legal institutions relies highly on economic growth and human-capital accumulation. Recent studies have investigated how legal institutions secure a successful transition from a central planning economy into a market economy (for example, Godoy and Stiglitz 2006). As the largest transition economy that has adopted the gradual reform approach, China provides an interesting case illustrating how the high pace of economic growth and the gradual evolution of legal institutions interact during the transition process.

It is not surprising that Chinese labor laws and labor institutions are underdeveloped during economic transitions. In a state-dominated economy, there is little conflict between management and unions since they equally serve the State and are under the direct supervision of the State-Party. The major task of unions is not to represent and protect the interests of the employees, but to administer a large part of the State-Party’s social and welfare provisions of the enterprises. There is, in effect, no collective bargaining between 
unions and management, with some recent exceptions. Unions collaborate with management to improve production efficiency. Unions are actually a part of the government administration and enterprise management. Neither labor laws nor the unions play important roles in regulating industrial relations.

The transition into a market economy and globalization has fundamentally changed the dynamics of industrial relations and increased the importance of private economic activities, which are not under the supervision of the government. The tensions between employers and employees, especially in the non-state sector, keep on arising. Employers might pursue profit maximization at the expense of the employees' interest. It has been well observed that the employees in a non-state enterprise are less protected, and that there is a rapid increase in labor disputes and social unrest. A successful economic transition needs for labor institutions to represent the employees and for labor laws to regulate industrial relations in order to effectively protect the interests of employees.

The Chinese government recognizes that a market economy can be successfully established only when labor rights are properly protected. The protection of labor rights becomes the central issue of Chinese labor legislation. The Constitution recognizes several labor rights including the right to work (Article 42), the right to rest (Article 43), and other labor rights. The most significant improvement in labor legislation is the Labor Law revisions made in 1994, which defined the minimum terms and conditions of employment. It sets out the provisions on promotion of employment, labor contracts and collective contracts, working hours and vocation, wages, health and safety, special protection for female and juvenile workers, training, social insurance and welfare, labor disputes resolution, supervision and inspection, and other legal responsibilities of the employees. The Labor Law of 1994 formally introduces the labor contract to replace the guaranteed lifetime employment. A majority of workers are gradually included in the labor contract system, which mainly 
consists of individual labor contracts instead of collective contracts. Collective labor contracts were introduced in Unions Law in 1992 and were reinforced in the 1994 Labor Law. The Labor Contract Law, which was implemented in 2008, intends to regulate the negotiation of labor contracts and to promote collective contracts.

The legal rules governing trade unions come from the Labor Law of 1994, the revised Trade Union Law in 1992 and 2001, and the Trade Union Constitution of 1998. The 1994 Labor Law recognizes that, "Workers have the right to participate in and organize trade unions according to the law. Trade unions represent and safeguard the legitimate rights and interests of workers, and independently conduct their activities” (Article 7, Chapter 1). The Trade Union Laws and Trade Union Constitution also recognize the legal rights of Chinese employees to organize or to join trade unions. However, according to the Trade Union Law, the All-China Federation of Trade Unions (ACFTU) is the only permitted official union organization, and all unions must be approved by and under the leadership of the ACFTU. There is no other independent union or labor institution in China.

The roles of unions are ambiguous as the Chinese unions serve multiple purposes: first, to serve administrative function of the Party-State to maintain social and political stability; second, to collaborate with enterprise management to harmonize industrial relations and to improve production efficiency; and third, to represent and protect the interests of employees. These objectives are increasingly contradictory: on the one hand, unions are required to be a social partner of government and enterprise management; and on the other hand, unions are required to be the representative of the employees against the interests of management during collective bargaining process. The unions' function in organizing workers' collective activities is in conflict with the Party-State’s objective of maintaining social and political stability. 
Chinese unions feature a unique hierarchical structure. At the top level organization is the ACFTU. The bottom level units are the workplace unions. At the intermediate level, there are two strands of unions: industrial unions and regional unions. Compatible with the administrative level of regions, regional unions are categorized at the province-level, city/county-level and town-level unions. For large cities, district-level unions may exist in between city-level and workplace unions. This type of organizational structure remains largely unchanged since the People’s Republic of China was established in 1949. The Party-State and the workers are connected through this "transmission belt": the "Party-State's voice” could be effectively transmitted from the top to the bottom level workplaces and, ideally, the employees' collective voice could be transmitted from the bottom to the top level and reach the policy makers. However, most studies on Chinese unions have found that the bottom-up transmission of the collective voice does not work well (for example, Chan 2000; Taylor et al. 2003; Metcalf and Li 2006). Chan (2000) argued that the top-down transmission of State-Party’s voice suppressed the bottom-up transmission relating to workers' interests. The union leaders and officials are not elected by the union members. Instead, they are appointed by the State-Party and belong to the government administration. They tend to follow strictly the order from the above-level, and thus neglect the voice from workplace employees. They are responsible to the State-Party but not to the union members whom they are supposed to represent and protect. The worry about unions’ only serving the State-Party's political objectives instead of representing and protecting the interests of employees is the most important reason why most scholars consider Chinese unions not as "real” unions but as “the Party’s organs” or “the arm of the State-Party” (Taylor et al. 2003; Chang 2000).

The finances of Chinese unions are also unique. According to the Trade Union Law, unionized enterprises are the main sponsors of unions: they are mandated to deliver two (2) percent payroll levy to regional unions or local government authorities. Five (5) percent of 
this fund is transferred to ACFTU headquarter in Beijing, 38\% is shared by industrial and regional unions, and 57\% return to workplace unions (Metcalf and Li 2006). This pay scheme avoids the direct financial control of enterprises over workplace unions and reinforces the top-down control within the union hierarchy. The rationale of this levy is that, "Unions are supposed to help enterprises to improve efficiency.” It is not surprising that enterprises, especially private and foreign-invested enterprises, strongly resist this levy: Some delay payment, some pay less or even refuse payment. Another source of union revenue is a levy of $0.5 \%$ of the wages of union members, and this fund directly goes to the workplace unions. However, Metcalf and Li (2006) show that this levy is seldom enforced because of the worry that the workers might question the service and representation of unions. Other less important finance sources include income from unions’ profitable activities, and from the local government subsidy to unions.

What do unions do in China?

Subordination to the State-Party does not imply that Chinese unions serve merely as the "transmission belt" between the State-Party and the majority of workers. To retain social and political stability during economic transitions, the State-Party recognizes that the unions need to be more effective in representing and protecting the employees' interests. Chinese unions are actually involved in a much wider range of activities than the standard unions in an advanced economy.

[Table 1 about here]

Based on the information from the Chinese Trade Union Statistics Yearbook 2005 (Research Department of ACFTU 2006), we summarize the activities of Chinese unions in Table 1. Panel A of Table 1 shows that Chinese unions represent the employees in collective consultations/bargaining with management. The Chinese Trade Union Laws grant the unions the right to collectively consult and to sign collective contracts with employers. The ACFTU 
initiated and promoted collective contracts to protect the employees’ right (Warner and Ng 1999; Taylor et al. 2003; Clarke et al. 2004). In 2004, about 32.5\% of unionized workplaces have established an equal consultation and collective bargaining system, and about $17.5 \%$ of unionized workplaces have established a wage negotiation system. Industrial and regional unions are in charge of industrial and regional level collective bargaining: about 107,290 regional collective contracts and 36,455 industrial collective contracts were signed in 2004. About 25.8 million employees are covered by regional collective contracts and about 17.1 million employees are covered by industrial collective contracts. These numbers suggest that Chinese unions do represent a significant proportion of the employees in collective bargaining with management. However, what really matters is the content of collective contracts, which only includes the minimum terms of employment that are already prescribed by the labor law, and thus provides the employees with few or no benefits. Clarke et al. (2004) described the collective consultation/bargaining process and concluded that, "The role of collective consultation in the Chinese enterprise is not to negotiate the terms and conditions of employment between the employer and employees, but at best to monitor the enforcement of labor law and the implementation of labor regulations” (p. 251). Without a strike weapon, unions are often subordinated to management and not treated as equal bargaining partners in the collective contracts signing process. The wage system in the private sector is usually based on individual labor contracts that consist of "performance related pay, low social welfare and insecure employment” (Metcalf and Li 2006). Given the weak bargaining power of unions and the lack of "real" content in collective contracts, it is fair to say that Chinese unions lack a “monopoly” face.

Panels B to E in Table 1 report the activities related to the "collective voice" face of unions. Unions consult with their members on labor-related issues such that "the proposals of management of the trade union were referred to lower levels for discussion, and their 
comments and recommendations were reported back to the enterprise trade union for its consideration” (Clarke et al. 2004). Unions accept the employees’ grievances and mediate between employees and employers. About $10.1 \%$ of unionized workplaces have established a Labor Dispute Mediation Committee (LDMC) to mediate in labor disputes. Of 192,119 labor dispute cases received in 2004, about 28.4\% were successfully mediated by LDMC. Unions are also charged with monitoring/supervising the implementation of labor law in workplaces: for example, the implementation of minimum wage and work safety regulations. About 149,424 workplace unions have established Labor Legal Supervision Organizations. In 2004 23,482 cases were accepted and $44.6 \%$ were successfully handled by the unions. About 182267 workplace unions have established Labor Protection Supervision and Inspection Committees, and 53,550 cases were accepted in 2004. A similar mediation/supervisory organization has been established by the industrial and regional unions. These institutions accept the employees' grievances and supervise the labor condition and the implementation of labor law. Industrial and regional unions have also established 2,990 Legal Aid Organizations, which provide legal consultation service or even directly send the union lawyers to help their members in the lawsuits. There are 6,684 industrial or regional unions establishing the tripartite system. With this system, unions are able to coordinate with the branches of the Ministry of Labor and the National Enterprises Association to solve labor disputes and other labor-related issues.

However, some studies question the effectiveness of the "collective voice” face of unions. For example, Clarke et al. (2004) argued that the consultation of unions with their members is more likely an exercise in propaganda and persuasion instead of an active participation of the membership. Chen (2003) argued that the State-Party's attitude strongly affects the “collective voice” face of unions. Unions are able to represent and protect the individual workers as long as it does not arouse group dissatisfaction and social disturbance. 
"When worker discontent bursts into spontaneous collective action, however, unions usually avoid representing, opting instead for mediation. Finally, if workers choose to form their own organizations independent of official unions, the latter would firmly adhere to the State's position and spare no effort to forestall, co-opt or prevent them.” (Chen 2003, p. 1008)

Panels F to I in Table 1 show various services and welfare benefits provided by unions to their members. Chinese unions retain their traditional role of social welfare provider; for example, unions provide financial support to employees in difficulty (or poverty); Unions establish various employee mutual cooperative insurance programs such as cooperative medical insurance, pension and industrial injury insurance programs. Unions serve their members through union-owned cultural and entertainment facilities such as clubs, cultural palaces, libraries, gyms, and stadiums. Industrial and regional unions have established 2,602 employment agencies to assist workers in re-employment.

Panels $\mathrm{J}$ to $\mathrm{M}$ in Table 1 report production-related union activities. Technology innovation is an important task of Chinese unions. Workplace unions promote a so-called “rationalization proposals” campaign, in which the employees’ production-related suggestions are delivered to management. There are 22,965 workplace unions establishing Technical Cooperation Organizations (TCOs), which have about 2.1 million members (about 0.8\% of total urban employees). In 2004 TCOs carried 54,147 innovation projects with an estimated value of about 5,749 million Yuan, and 3,265 industrial and regional unions established TCOs to promote the innovation and adoption of new technology.

Chinese unions also directly provide an employee training service. The TCOs of workplace unions have organized 43,578 technical contests and 89,313 training lectures. Industrial and regional unions have established independently 1,038 employee education institutions, including colleges, technical secondary schools, spare-time schools, training centers, and re-employment training bases. There were about half a million employees 
enrolled in these institutions in 2004.

Panel N of Table 1 reports union activities related to corporate governance. Trade Union Law (2001 Revision) grants the unions the right to participate in democratic management on behalf of workers. Among 2 millions unionized workplaces, about 15.8\%, have established worker congresses. About 2.2\% of workplaces have established Supervision Committees and 1.1\% have union chairs in the Supervision Committees. About 2.9\% of workplaces have established Boards of Directors and 1.3\% have union chairs in the Board of Directors. However, a union chair is not elected by union members, but is usually an official appointed by upper-level unions. In many enterprises, the union chair is at same time the chair or vice chair of a human resource department, and subordinated to management. It is questionable how effectively the union chair could represent the employees in a "democratic" management.

There are a number of other union activities not reported in Table 1. For example, at the national level, the ACFTU actively participates in labor-related law and policy making and lobby for measures to protect workers’ interests. Industrial and regional unions also participate in local labor regulation and policy making process. At the grassroots level, workplace unions organize various cultural and sport events. They also arrange holiday trips for their members and even organize summer camps for their members' children. In addition, birth control is also an important task of unions in the public sector.

In summary, Chinese unions not only function as a "transmission belt,” but also participate in a wide range of activities. They represent their members in collective consultation/bargaining with management, accept employees’ grievances, mediate labor disputes, monitor work conditions and the implementation of labor law, provide various services and welfare benefits to the employees, promote technology innovation and employee training, and participate in corporate governance and policy making. The effectiveness of 
these activities, however, needs to be carefully examined.

Previous empirical evidences on Chinese unions, which are based on case studies, suggest that Chinese unions cannot effectively protect the rights and interests of employees, especially in non-state enterprises. For example, Chen (2003) provided several case studies to show that the representation role of unions has been highly restricted because their influence stems not from organized labor but from their official institutional status. Metcalf and Li (2006) investigated three unionized non-state enterprises in the Hainan province and found that the workplace unions are weak in collective bargaining and dispute resolution, and just play a welfare role. They concluded that Chinese unions cannot impose costs on the enterprises, and neither can they improve the efficiency of enterprises. However, these case studies lack a systematic comparison between unionized and non-unionized enterprises. The employees in non-unionized workplaces might be significantly less protected since there is no labor institution representing their interests at all. Recent studies based on firm survey data have suggested a different pattern. For example, Lu et al. (2010) used the Private Enterprise Survey data and found the positive link between unions and employee benefit and enterprise productivity. Based on a survey of 1268 firms in 12 Chinese cities, Yao and Zhong (2013) found that unions have positive effects on employee welfare. In this paper, we use the national firm level data to investigate the effects of presence of unions on firm performance.

\section{Unions and Enterprise Performance}

There is a substantial literature on linkages between unions and economic performance of the firms. For a U.S. study, Freeman and Medoff (1984) found that, in general, unions tend to increase productivity while they lower profitability. Hirsch (2004) summarized the empirical studies on this topic since the publication of What Do Unions Do? and concluded that the average union productivity effect is very close to zero. The existing evidence also 
suggests significantly lower profitability among unionized firms compared to their non-union counterparts. Metcalf (2003) surveyed the empirical evidence from six countries: the U.S., Canada, the UK, Germany, Japan and Australia, and he showed that there is no clear cut for the international evidence. Consistent with the view of Freeman and Medoff (1984) and Hirsch (2004), Metcalf concluded that union productivity effects depend heavily on the environment, especially on the interaction between a high-performance work system and unions. The international evidence also pointed to lower profit or financial performance in unionized workplaces, and that unionization has reduced investments for all countries except Japan.

\section{Unions and Profitability}

In the case of China, unions have little monopoly power in collective bargaining with management, and thus successful union rent-seeking is less likely. However, the presence of unions in the workplace may increase production costs. First, the State/Party voice and collective voice of unions may exert pressure on management to alleviate the exploitation of employees and thus increase labor costs. The empirical evidence in the previous section suggests that unionization is significantly and positively associated with enterprise average wage and benefits. Second, unionized enterprises are mandated to deliver a $2 \%$ payroll levy to the unions, which directly increases production costs. If the productivity gain of unionization does not offset the increasing production costs, then unionization will lower profitability and thus engenders management resistance.

To investigate the linkage between unions and firm profitability, we regress firm profit on unionization, the presence of unions in same industry and region, and other control variables. Profit is measured by the rate of return on capital, indicated by net income divided by total assets. The control variables include industry dummies, region dummies, ownership 
dummies, firm size, and capital-labor ratio. ${ }^{1}$

[Table 2 about here]

Columns 1 and 2 of Table 2 report the OLS results. The results suggest that profitability is significantly different across ownerships: private enterprises are most profitable, followed by COEs and domestic enterprises with mixed ownership. Foreign and Hong Kong/Macau/Taiwan (HMT)-invested enterprises are less profitable than domestic non-state enterprises, and SOEs are the least profitable. The low profitability of FIEs is surprising since FIEs are usually efficient and offer the high level of wages. A possible explanation for this is that multinational firms use intra-firm transfers to allocate taxable income across countries and to reduce global tax liability.

For the effects of unions, the estimated coefficient of the union dummy is -0.060 and significant at the $1 \%$ level. The estimated coefficient of union density is -0.063 and significant at the $1 \%$ level. These results suggest that unionized firms are less profitable than non-unionized counterparts. To identify the different impact of unions across different ownership categories, we include the interaction between unions and ownership into the regression and the results are shown in Column 3 and 4 . The evidences suggest that the negative effect of unions on profitability is most severe in COEs and private firms, followed by domestic joint ventures. The impact is least significant in HMT and foreign invested enterprisers. The results also show that the presence of unions in same industry and region tend to reduce the profitability of firms, suggesting negative spillover effects. Our findings

${ }^{1}$ The definitions of these variables are the same as those in the wage equation. Hirsch (1991) included more firm-level control variables, such as R\&D intensity, advertising intensity, and sales growth, in profit-function estimation. Unfortunately, our data set does not include information on $R \& D$ and advertising expenditures. The information on sales growth is not available since we only have cross-section data. 
are consistent with the international experience of the negative effect of unionization on profitability (Metcalf 2003; Hirsch 2004).

\section{Unions and Productivity}

The theoretical prediction on union productivity is ambiguous. According to the standard framework of two-faces of unionism (Freeman and Medoff 1984), the monopoly face of unions might decrease efficiency through wage distortion, contractual work rules, reduced work incentives, limited managerial discretion, and reduced capital investment. In contrast, the collective voice face of unions might enhance efficiency through improving internal labor relations, reducing turnover cost, reducing organizational slack, encouraging employee involvement in production, and creating conditions that motivate a greater work effort. ${ }^{2}$ Both productivity-enhancing union effects and productivity-detracting effects could occur simultaneously and offset each other, and the relative importance depends highly on the economic and regulatory environment.

The case of China might be somewhat unique because Chinese unions lack a "monopoly” face but have a "collective voice” face and a strong "State-Party voice” face. There are several channels through which the presence of unions might have "real" effect on firm productivity. First, Chinese unions are unable to extract monopoly gains for their members, and thus the efficiency loss caused by the monopoly face of unions is unlikely. Second, Chinese unions are subordinated to the State-Party. The State-Party's political interests might conflict with the interests of the enterprises and the employees. Through the union system, the State-Party might interfere with enterprise operations, reduce managerial discretion and thus reduce efficiency. Third, unions participate in the regulation of employment relationships and the corporate governance of enterprises. The "collective voice" face of unions may have efficiency-enhancing effects. Fourth, one of major objectives of

\footnotetext{
2 See the survey in Kaufman (2004)
} 
Chinese unions is to help enterprises to improve production efficiency. Chinese unions participate in various activities such as rationalization proposal activities, technology innovations and contests, and employee training. These activities might directly contribute to higher enterprise productivity.

To investigate the linkage between unions and firm productivity, we estimate the following augmented Cobb-Douglas production function:

$$
\begin{aligned}
\log \left(Y_{i}\right)= & \alpha+\beta_{L} \log \left(L_{i}\right)+\beta_{K} \log \left(K_{i}\right)+\lambda_{1} \text { Unionization }_{i}+\lambda_{2} \text { Union }_{-} \text {presence }_{j k} \\
& +\sum \delta_{j} I_{i j}+\sum \theta_{k} R_{i k}+\sum \eta_{m} O_{i m}+\gamma X_{i}+\varepsilon_{i}
\end{aligned}
$$

where $Y_{i}$ is the value added of enterprise $\mathrm{i}^{3} ; L_{i}$ is the employment of enterprise $\mathrm{i}, K_{i}$ is the capital of enterprise i. Unionization ${ }_{i}$ is measured by the union dummy and union density; Union $_{\text {_ }}$ presence $_{j k}$ is the share of union members in total employees of industry $\mathrm{j}$ and region $\mathrm{k} ; \quad I_{i j}$ is the industry dummy, which captures the industry-specific productivity differentials. $R_{i k}$ is the location dummy, which captures the regional-specific productivity differentials. $O_{i m}$ are five ownership dummies: SOEs, COEs, private firms, HMTIEs, and FIEs. The benchmark is domestic joint ventures. For control variables $X_{i}$, previous studies show that several factors, such as managerial ability, technology usage, worker composition, international exposure and regulation environment, are closely related to productivity (Bartelsman and Doms 2000). Based on the limited information of our data set, we consider three variables: gender composition, skill composition and technology usage. Worker gender composition is measured by the proportion of female workers in total workers. Skill composition is measured by the proportion of workers with different education levels.

\footnotetext{
${ }^{3}$ The information of value added is only available for the limited sample, which includes most of SOEs and large and medium sized non-state enterprises (with total sales roughly above 5 million Yuan).
} 
Technology usage is measured by the logarithm of (one plus the number of computers used in workplace). $\alpha$ is a constant; and $\varepsilon_{i}$ is the idiosyncratic productivity shock.

[Table 3 about here]

Columns 1 and 2 of Table 3 report the OLS results of the production-function estimation for two measures of unionization: the union dummy and the union density. The estimated elasticity of value added relative to capital and labor are 0.23 and 0.48 , respectively. Ownership structure has a significant effect on productivity. Private enterprises and COEs are the most efficient, followed by FIEs and domestic joint ventures. SOEs are the least efficient. Share of female workers has significant and negative effects on productivity, implying a gender productivity differential. Skill composition and technology usage have a significant and positive impact on enterprise efficiency. For the effects of unions, the estimated coefficient of the union dummy is 0.026 , and the estimated coefficient of union density is 0.033 , and significant at the $1 \%$ level. These results suggest that unionization is significantly and positively associated with enterprise productivity. However, the effectiveness of unions might vary across ownership. Columns 3 and 4 of Table 3 report the results when we include the interaction terms between ownership types and unionization. The results suggest that the effects of unions on productivity are significantly different across ownership categories. The presence of unions in state and foreign firms has a significantly positive impact on the productivity, while the effects become insignificant for domestic joint ventures and private firms. The unions are negatively associated with productivity in COEs. This finding is quite consistent with the union effects on firm profitability. The estimated coefficient of union presence in same region and industry is about -0.17 , suggesting negative spillovers within industry and region on productivity.

In summary, our analysis suggests that Chinese unions not only function as a “transmission belt” of the State-Party, but also significantly affects enterprise performance. 
The presence of unions in workplaces significantly reduces enterprise profits, and the negative effects are most severe in COEs and private firms. The presence of unions is positively associated with productivity in SOEs and foreign firms, but negatively related with efficiency in COEs. Moreover, the presence of unions within same region and industry generates negative spillovers on enterprise performance. One concern of this study is that unionization is not exogenous when good firms are more likely to be unionized. This self-selection bias might not be a serious concern in case of China. As discussed in previous section, unionization requests come mainly from the State-Party through the top-to-bottom persuasion of intermediate level unions. Unionization is mainly driven by political concerns for extending the State-Party's connection with the workers and for retaining social and political stability. Moreover, the target of ACFTU on good firms is not consistent with the negative link between unions and firm performance. Private firms, COEs and FIEs, which are the most productive firms but have the lowest unionization levels.

\section{Conclusion}

Our study investigates trade unions in a transition economy with rapid economic growth. We summarize labor legislation, organizational structure and the activities of Chinese unions. Based on an enterprise population level data, we empirically examine the linkage between unionization and firm performance.

In this paper we develop the following twofold view: First, trade unions in China are underdeveloped. Chinese unions have a strong "State-Party voice” face in that unions have a hierarchal structure and are subordinated to the State-Party and function as a "transmission belt” between the State-Party and the workers. The government influence plays an important role in the unionization process. On the other hand, unlike the Western independent unions, Chinese unions lack a “monopoly” face since they have only a weak bargaining power in 
collective consultation / bargaining with management. The collective labor contracts promoted by the unions lack a real content and provide the employees few benefits in collective bargaining/consultation.

Second, Chinese unions not only serve the interest of the State-Party, but can also effectively affect the employee welfare and the firm performance. The unions participate in a wide range of activities such as accepting the employees’ grievances, mediating in labor disputes, monitoring the implementation of labor law, providing various services and welfare assistance to the employees, promoting technology innovation and employee training, and participating in corporate governance and policy making. These activities of unions might significantly affect both enterprise performance and employee interests. The empirical evidences suggest that Chinese unions have some "real" effects on firm performance. There are systematic differences between unionized and non-unionized enterprises. The presence of unions is positively associated with employee wages and benefits, but is negatively related to enterprise profit. The evidences are mixed for productivity. We show that the presence of unions has a significant and positive effect on productivity in SOEs and foreign firms, but a negative effect on the efficiency in COEs. Unions have negative spillovers on productivity within same industry and region.

Economic development in China calls for an improvement in Labor Law and Trade Union Law to grant the unions an independent status, to separate the unions from both State-Party and enterprise management, and to clarify that the major objective of the unions is to represent and protect the interests of employees. However, independence from the State-Party may not be sufficient to support a successful development of the unions. In a unique political, legal and economic environment, without the support of the State-Party's administrative power, even the survival of unions is threatened by the strong resistance of management. In a comparative study of trade unions in China and Russia, Clarke (2005) 
showed that unions in Russia, which have rapidly obtained independent status, have difficulties developing their ability to defend the employees' interests, and have to turn back to their traditional social-political and management functions.

This implies that it is inappropriate to analyze post-socialist trade unions in terms of their development towards one or another existing model of trade unionism, because they have to construct their own trade unions practice on the basis of inherited structure and within a framework that is outside their control. (Clarke, 2005, p. 2)

One would not expect China to completely abandon the current union system and to adopt the standard model in an advanced economy. For an institutional reproduction in the short run, Chinese unions have to retain their traditional role in collaborating with the State-Party and management. For development in the long run, they need to improve their ability to represent and protect the employees’ interests. With increased conflicts between these objectives during economic transitions, it is a challenge for Chinese unions to find a suitable evolution path to boost economic development while securing their independent roles and functions to protect the interests of the union members.

This study is intended to enhance our understanding of the activities and effectiveness of Chinese unions. We show that the effectiveness of unions are significantly different across ownership, but the mechanisms through which Chinese unions function under different ownership structure, corporate governance, and environments remain unclear. Future studies should call for a firm-level panel dataset in order to control for the unobservable fixed characteristics and to investigate the dynamic changes of unionism. Individual-level data are also needed to compare the differences between union and non-union workers. Future studies need to develop a better understanding of the mechanism through which unions affect firm performance in the unique social, economic, and regulatory environment of the largest transitional economy in the world. 


\section{Reference}

Bartelsman, Eric, and Mark Doms. 2000. "Understanding Productivity: Lessons from Longitudinal Microdata.” Journal of Economic Literature, Vol. 38, No. 3, pp. 569-594.

Blanchflower, David G., and Alex Bryson. 2004. "What Effect do Unions have on Wages now and Would Freeman and Medoff be Surprised?” Journal of Labor Research, Vol. 25, No. 3, pp. 381-414.

Budd, John W. 2004. “Non-wage Forms of Compensation.” Journal of Labor Research, Vol. 25, No. 4, pp. 597-622.

Chan, Anita. 2000. “Chinese Trade Unions and Workplace Relations in State-owned and Joint-venture Enterprises.” In Malcolm Warner, ed., Changing Workplace Relations in the Chinese Economy, pp. 34-56. Macmillan Press Ltd.: Basingstoke and London.

Chen, Feng. 2003. "Between the State and Labour: the Conflict of Chinese Trade Unions' Double Identity in Market Reform.” The China Quarterly, Vol. 176, pp. 1006-1028.

Clarke, Simon. 2005. “Post-socialist Trade Unions: China and Russia.” Industrial Relations Journal, Vol. 36, No. 1, pp. 2-18.

Fang, Tony and Ge Ying. 2012. “Unions and Firm Innovation in China: Synergy or Strife?” China Economic Review, Vol. 23, No. 1, pp. 170-180.

Clarke, Simon, Chang-Hee Lee, and Qi Li. 2004. “Collective Consultation and Industrial Relations in China.” British Journal of Industrial Relations, Vol. 42, No. 2, pp. 235-254. Freeman, Richard B. 2005. “What do Unions do? The 2004 M-Brane Stringtwister Edition.” Journal of Labor Research, Vol. 26, No. 4, pp. 641-668.

Freeman, Richard B., and James Medoff. 1984. What do Unions do? New York: Basic Books. Godoy, Sergio, and Joseph E. Stiglitz. 2006. “Growth, Initial Conditions, Law and Speed of Privatization in Transition Countries: 11 Years Later.” NBER Working Paper No. 11992. 
Hirsch, Barry T. 1991. “Union Coverage and Profitability among U.S. Firms.” Review of Economics and Statistics, Vol. 73, No.1, pp. 69-77.

—_. 2003. "Reconsidering Union Wage Effects: Surveying New Evidence on an Old Topic.

The Institute for the Study of Labor, Bonn. Mimeo.

—. 2004. "What do Unions do for Economic Performance?” Journal of Labor Research, Vol. 25, No. 3, pp. 415-55.

Kaufman, Bruce E. 2004. “What Unions do: Insight from Economic Theory.” Journal of Labor Research, Vol. 25, No. 3, pp. 351-382.

Lu, Yi, Zhigang Tao, and Yijiang Wang. 2010. “Union Effects on Performance and Employment Relations: Evidences from China.” China Economic Review, Vol. 21, No. 1, pp. 202-210.

Metcalf, David. 2003. "Unions and Productivity, Financial Performance and Investment: International Evidence.” In: Addison, John, Schnabel, Claus (Ed.), International Handbook of Trade Unions, 118-171. Northampton, Mass.: Edward Elgar.

Metcalf, David, and Jianwei Li. 2006. "Chinese Unions: an Alice in Wonderland Dream World.” Advances in Industrial and Labor Relations, Vol. 15, No.1, pp. 213-268.

National Bureau of Statistics of China. 2006. China Economic Census Yearbook. Beijing: China Statistics Press.

North, Douglass C. 1990. Institutions, Institutional Change and Economic Performance. Cambridge: Cambridge University Press.

Research Department of All China Federation of Trade Union. 2006. Chinese Trade Unions Statistics Yearbooks 2005. Beijing: China Statistics Press.

Taylor, Bill, Kai Chang, and Qi Li. 2003. Industrial Relations in China. Cheltenham: Edward Elgar Publishing Limited. 
Warner, Malcolm, and Sek-Hong Ng, 1999. “Collective Contracts in Chinese Enterprises: a New Brand of Collective Bargaining under Market Socialism.” British Journal of Industrial Relations, Vol. 37, No. 2, pp. 295-314.

Yao, Yang, and Ninghua Zhong. 2013. Journal of Labor Economics, Vol. 31, No. 3, pp. 633 667. 
Table 1

Activities of Chinese Unions in 2004

Workplace Unions

Industrial and Regional Unions

Panel A: Collective Consultation and Bargaining

Unionized workplaces with equal consultation and

collective contract system

Unionized workplaces with wage negotiation system

628819 Number of regional collective contracts

107290

339379 Employees covered by regional collective contracts (million)

25.8

Number of industrial collective contracts

36455

Panel B: Labor Dispute Mediation / Arbitration

Employees covered by industrial collective contracts (million)

17.1

Workplaces with Labor Dispute Mediation Committee

195403 Industrial and regional labor dispute mediation /arbitration

(LDMC)

Number of labor dispute cases accepted by LDMC organizations

Number of labor dispute cases successfully mediated

192119 Number of labor dispute cases accepted

54537 Number of labor dispute cases handles by union labor dispute 14731 arbitrators

Unions with tripartite system

Panel C: Labor Legal Supervision

Workplace unions with Labor Legal Supervision

149424 Unions establishing Labor Legal Supervisory Organizations

Organizations

Number of case accepted

23482 Number of case accepted

34693

Number of cases handled by unions

10477 Number of cases handled by unions

Panel D: Labor Protection Supervision

Workplace unions with Labor Protection Supervision 182267

and Inspection Committees

Panel E: Legal Aid

\begin{tabular}{lllc}
\hline & & & \\
& & Unions with Legal Aid Organizations & \\
Number of cases accepted & \\
\hline Panel F: Financial Support to Employees with Difficulty & & & \\
\hline Workplace unions with Warmth Delivery Project Fund & 36794 & Unions with Warmth Delivery Project Fund \\
The balance of fund (million Yuan) & 1147.8 & The balance of fund (million Yuan) & 6185 \\
& & Unions with supporting center for employees in poverty & 2149.0 \\
& & Employees supported (million persons) & 1786 \\
\hline
\end{tabular}




\begin{tabular}{|c|c|c|c|}
\hline \multicolumn{4}{|l|}{ Panel G: Employee Mutual Cooperative Insurance } \\
\hline $\begin{array}{l}\text { Workplace unions with employee mutual cooperative } \\
\text { insurance program }\end{array}$ & 31280 & $\begin{array}{l}\text { Industrial and regional unions with employee mutual cooperative } \\
\text { insurance program }\end{array}$ & 1880 \\
\hline The employees joining the program (million person) & 8.3 & The employees joining the program (million person) & 2.0 \\
\hline Union-owned clubs and cultural palaces & 23370 & Union-owned clubs and cultural palaces & 1623 \\
\hline Union-owned libraries & 11648 & Union-owned libraries & 406 \\
\hline Union-owned gyms and stadiums & 13376 & Union-owned gyms and stadiums & 865 \\
\hline & & Number of employees succeeded (million person) & 3.8 \\
\hline \multicolumn{4}{|l|}{ Panel J: Employee Rationalization Proposal Activities } \\
\hline Number of rationalization proposals & 6510729 & & \\
\hline Number of rationalization proposals in practice & 2617430 & & \\
\hline $\begin{array}{l}\text { The value created by implementing rationalization } \\
\text { proposals (million Yuan) }\end{array}$ & 25391.9 & & \\
\hline Workplace unions with TCOs & 22965 & Unions with Technical Cooperation Organizations (TCOs) & 3265 \\
\hline Number of innovation projects carried by TCOs & 54147 & Number of innovation projects promoted by TCOs & 26721 \\
\hline \multicolumn{4}{|l|}{ Panel M: Employee Training } \\
\hline Times of technical contests organized by TCOs & 43578 & Number of employee education institutions owned by unions & 1038 \\
\hline Timed of technical training lectures & 89313 & The number of employees enrolled in these institutions & 502460 \\
\hline \multicolumn{4}{|l|}{ Panel N: Corporate Governance } \\
\hline Unionized workplaces with worker congress & 305775 & & \\
\hline Unionized workplaces with the Supervision Committee & 41910 & & \\
\hline Union chairmen in the committee & 20907 & & \\
\hline Unionized workplaces with the board of directors & 56573 & & \\
\hline Union chairmen in the board & 25268 & & \\
\hline
\end{tabular}




\section{Table 2}

Unions and Profitability

\begin{tabular}{|c|c|c|c|c|}
\hline & $(1)$ & $(2)$ & (3) & $(4)$ \\
\hline SOEs & $\begin{array}{c}-0.044 * * * \\
(-26.97)\end{array}$ & $\begin{array}{c}-0.044 * * * \\
(-26.88)\end{array}$ & $\begin{array}{c}-0.051 * * * \\
(-15.07)\end{array}$ & $\begin{array}{c}-0.058 * * * \\
(-19.26)\end{array}$ \\
\hline COEs & $\begin{array}{c}0.036 * * * \\
(36.93)\end{array}$ & $\begin{array}{c}0.036 * * * \\
(36.98)\end{array}$ & $\begin{array}{c}0.038 * * * \\
(31.50)\end{array}$ & $\begin{array}{c}0.039 * * * \\
(32.95)\end{array}$ \\
\hline Private enterprises & $\begin{array}{c}0.063 * * * \\
(81.55)\end{array}$ & $\begin{array}{c}0.065 * * * \\
(82.72)\end{array}$ & $\begin{array}{c}0.063 * * * \\
(65.68)\end{array}$ & $\begin{array}{c}0.064 * * * \\
(69.55)\end{array}$ \\
\hline HMT invested enterprise & $\begin{array}{c}-0.020 * * * \\
(-17.06)\end{array}$ & $\begin{array}{c}-0.021^{* * *} \\
(-18.45)\end{array}$ & $\begin{array}{c}-0.044 * * * \\
(-31.92)\end{array}$ & $\begin{array}{c}-0.040 * * * \\
(-29.95)\end{array}$ \\
\hline FIEs & $\begin{array}{c}-0.018 * * * \\
(-15.53)\end{array}$ & $\begin{array}{c}-0.018 * * * \\
(-15.74)\end{array}$ & $\begin{array}{c}-0.044 * * * \\
(-31.00)\end{array}$ & $\begin{array}{c}-0.040 * * * \\
(-29.46)\end{array}$ \\
\hline Size & $\begin{array}{c}0.020 * * * \\
(-140.4)\end{array}$ & $\begin{array}{c}0.019 * * * \\
(-135.4)\end{array}$ & $\begin{array}{c}0.021 * * * \\
(140.7)\end{array}$ & $\begin{array}{c}0.019 * * * \\
(135.5)\end{array}$ \\
\hline Capital labor intensity & $\begin{array}{c}-0.0003 * * * \\
(-153.9)\end{array}$ & $\begin{array}{c}-0.0003 * * * \\
(-152.2)\end{array}$ & $\begin{array}{c}-0.0003^{* * *} \\
(-155.4)\end{array}$ & $\begin{array}{c}-0.003^{* * *} \\
(-154.8)\end{array}$ \\
\hline Union dummy & $\begin{array}{c}-0.060 * * * \\
(-109.3)\end{array}$ & & $\begin{array}{c}-0.067 * * * \\
(-53.28)\end{array}$ & \\
\hline Union density & & $\begin{array}{c}-0.063^{* * *} \\
(-98.31)\end{array}$ & & $\begin{array}{c}-0.069 * * * \\
(-47.94)\end{array}$ \\
\hline SOE*unionization & & & $\begin{array}{c}0.014 * * * \\
(3.55)\end{array}$ & $\begin{array}{c}0.027 * * * \\
(6.90)\end{array}$ \\
\hline $\mathrm{COE}^{*}$ unionization & & & $\begin{array}{c}-0.010^{* * *} \\
(-5.62)\end{array}$ & $\begin{array}{c}-0.015^{* * *} \\
(-7.26)\end{array}$ \\
\hline Private* unionization & & & $\begin{array}{c}-0.004^{* * *} \\
(-2.50)\end{array}$ & $\begin{array}{c}-0.007 * * * \\
(-4.29)\end{array}$ \\
\hline HMTIEs* unionization & & & $\begin{array}{c}0.077 * * * \\
(34.41)\end{array}$ & $\begin{array}{c}0.088 * * * \\
(31.68)\end{array}$ \\
\hline FIEs* unionization & & & $\begin{array}{c}0.084 * * * \\
(38.85)\end{array}$ & $\begin{array}{c}0.099 * * * \\
(38.41)\end{array}$ \\
\hline $\begin{array}{l}\text { Union presence in same industry } \\
\text { \& province }\end{array}$ & $\begin{array}{c}-0.158 * * * \\
(-36.89)\end{array}$ & $\begin{array}{c}-0.159 * * * \\
(-37.04)\end{array}$ & $\begin{array}{c}-0.158 * * * \\
(-36.89)\end{array}$ & $\begin{array}{c}-0.158 * * * \\
(-37.03)\end{array}$ \\
\hline Industry Dummies & Yes & Yes & Yes & Yes \\
\hline Province Dummies & Yes & Yes & Yes & Yes \\
\hline R-square & 0.15 & 0.15 & 0.15 & 0.15 \\
\hline Observations & 1178647 & 1178647 & 1178647 & 1178647 \\
\hline
\end{tabular}


Table 3

Unions and Productivity

\begin{tabular}{|c|c|c|c|c|}
\hline & (1) & (2) & (3) & (4) \\
\hline Log (capital) & $\begin{array}{c}0.228^{* * *} \\
(116.6)\end{array}$ & $\begin{array}{c}0.228 * * * \\
(116.2)\end{array}$ & $\begin{array}{c}0.228^{* * *} \\
(116.4)\end{array}$ & $\begin{array}{c}0.227 * * * \\
(115.9)\end{array}$ \\
\hline Log (labor) & $\begin{array}{c}0.481^{* * *} \\
(147.6)\end{array}$ & $\begin{array}{c}0.482 * * * \\
(148.5)\end{array}$ & $\begin{array}{c}0.480 * * * \\
(146.3)\end{array}$ & $\begin{array}{c}0.483 * * * \\
(148.8)\end{array}$ \\
\hline SOEs & $\begin{array}{c}-0.815^{* * *} \\
(-57.7)\end{array}$ & $\begin{array}{c}-0.817 * * * \\
(-57.8)\end{array}$ & $\begin{array}{c}-1.005^{* * * *} \\
(-35.88)\end{array}$ & $\begin{array}{c}-0.934 * * * \\
(-37.35)\end{array}$ \\
\hline COEs & $\begin{array}{c}0.074 * * * \\
(9.27)\end{array}$ & $\begin{array}{c}0.074 * * * \\
(9.29)\end{array}$ & $\begin{array}{c}0.155^{* * *} \\
(13.45)\end{array}$ & $\begin{array}{c}0.136 * * * \\
(12.80)\end{array}$ \\
\hline Private enterprises & $\begin{array}{c}0.026 * * * \\
(4.58)\end{array}$ & $\begin{array}{c}0.027 * * * \\
(4.66)\end{array}$ & $\begin{array}{c}0.034^{* * *} \\
(4.17)\end{array}$ & $\begin{array}{c}0.024 * * * \\
(3.20)\end{array}$ \\
\hline HMT invested enterprise & $\begin{array}{c}-0.119 * * * \\
(-14.4)\end{array}$ & $\begin{array}{c}-0.118^{* * *} \\
(-14.3)\end{array}$ & $\begin{array}{c}-0.157 * * * \\
(-13.84)\end{array}$ & $\begin{array}{c}-0.164 * * * \\
(-15.64)\end{array}$ \\
\hline FIEs & $\begin{array}{c}0.021 * * \\
(2.55)\end{array}$ & $\begin{array}{c}0.021^{* * *} \\
(2.60)\end{array}$ & $\begin{array}{c}-0.037 * * * \\
(-3.22)\end{array}$ & $\begin{array}{c}-0.048 * * * \\
(-4.43)\end{array}$ \\
\hline Female share & $\begin{array}{c}-0.388 * * * \\
(-36.8)\end{array}$ & $\begin{array}{c}-0.389 * * * \\
(-36.8)\end{array}$ & $\begin{array}{c}-0.381 * * * \\
(-36.16)\end{array}$ & $\begin{array}{c}-0.381 * * * \\
(-36.10)\end{array}$ \\
\hline Graduate & $\begin{array}{c}1.265^{* * * *} \\
(9.24)\end{array}$ & $\begin{array}{c}1.267 * * * \\
(9.25)\end{array}$ & $\begin{array}{c}1.292 * * * \\
(9.46)\end{array}$ & $\begin{array}{c}1.282^{* * *} \\
(9.38)\end{array}$ \\
\hline College & $\begin{array}{c}0.515^{* * *} \\
(27.5)\end{array}$ & $\begin{array}{c}0.514 * * * \\
(27.5)\end{array}$ & $\begin{array}{c}0.520 * * * \\
(27.82)\end{array}$ & $\begin{array}{c}0.513^{* * *} \\
(27.46)\end{array}$ \\
\hline High school & $\begin{array}{c}0.087 * * * \\
(9.11)\end{array}$ & $\begin{array}{c}0.085^{* * *} \\
(8.97)\end{array}$ & $\begin{array}{c}0.089 * * * \\
(9.37)\end{array}$ & $\begin{array}{c}0.087 * * * \\
(9.19)\end{array}$ \\
\hline Technology usage & $\begin{array}{c}0.200 * * * \\
(69.4)\end{array}$ & $\begin{array}{c}0.200 * * * \\
(69.3)\end{array}$ & $\begin{array}{c}0.199 * * * \\
(69.02)\end{array}$ & $\begin{array}{c}0.199 * * * \\
(69.03)\end{array}$ \\
\hline Union dummy & $\begin{array}{c}0.026 * * * \\
(6.21)\end{array}$ & & $\begin{array}{c}0.020 * * \\
(2.04)\end{array}$ & \\
\hline Union density & & $\begin{array}{c}0.033 * * * \\
(6.29)\end{array}$ & & $\begin{array}{l}0.005 \\
(0.42)\end{array}$ \\
\hline SOE*unionization & & & $\begin{array}{c}0.253^{* * *} \\
(7.85)\end{array}$ & $\begin{array}{c}0.192 * * * \\
(5.75)\end{array}$ \\
\hline COE* unionization & & & $\begin{array}{c}-0.163 * * * \\
(-10.45)\end{array}$ & $\begin{array}{c}-0.172 * * * \\
(-9.41)\end{array}$ \\
\hline Private* unionization & & & $\begin{array}{c}-0.029 * * * \\
(-2.62)\end{array}$ & $\begin{array}{l}-0.014 \\
(-1.08)\end{array}$ \\
\hline HMTIEs* unionization & & & $\begin{array}{c}0.091 * * * \\
(5.80)\end{array}$ & $\begin{array}{c}0.157 * * * \\
(8.05)\end{array}$ \\
\hline FIEs* unionization & & & $\begin{array}{c}0.134^{* * *} \\
(8.47)\end{array}$ & $\begin{array}{c}0.215^{* * *} \\
(11.36)\end{array}$ \\
\hline $\begin{array}{l}\text { Union presence in same } \\
\text { industry \& province }\end{array}$ & $\begin{array}{c}-0.167 * * * \\
(-4.71)\end{array}$ & $\begin{array}{c}-0.168 * * * \\
(-4.73)\end{array}$ & $\begin{array}{c}-0.175^{* * * *} \\
(-4.93)\end{array}$ & $\begin{array}{c}-0.174 * * * \\
(-4.90)\end{array}$ \\
\hline Industry Dummies & Yes & Yes & Yes & Yes \\
\hline Province Dummies & Yes & Yes & Yes & Yes \\
\hline R-square & 0.52 & 0.52 & 0.52 & 0.52 \\
\hline Observations & 240897 & 240897 & 240897 & 240897 \\
\hline
\end{tabular}

Note: t-values are reported in parenthesis.*, ${ }^{* *}$, and $* * *$ represent $10 \%, 5 \%$, and $1 \%$ significance level, respectively. 